\title{
Dietary influences on the secretion into and degradation of mucin in the digestive tract of monogastric animals and humans
}

\author{
K.A. Lien, W.C. Sauer and J.M. He \\ Department of Agricultural, Food and Nutritional Science, \\ University of Alberta \\ Edmonton, Alberta, Canada T6G $2 P 5$
}

(Received 27 February 2001; accepted 20 April 2001)

\begin{abstract}
Current information on the effect of diet on the secretion of mucus and the recovery of mucin in ileal digesta is summarized. A general description of mucus structure and its degradation in the small and large intestine is provided. As the protective lining of the entire gastrointestinal tract, mucus gels are exposed to all chemical and physical forces of digestion. Most important among these is the proteolytic breakdown of mucus gels into component mucin subunits and their subsequent release into the intestinal lumen. Erosion of mucus gels is countered by synthesis and secretion from the underlying epithelium. Diets can influence this process, both indirectly by their effects on digestive processes most importantly with respect to the amount and distribution of proteolytic enzymes in the intestinal lumen, and directly by the physical forces which they exert on the gastrointestinal mucosa. Adaptive changes in goblet cell activity have been noted in response to different diets. Once in the intestinal lumen, little further degradation of mucus occurs prior to the large intestine. Once in the large intestine mucin is fermented by resident microbial populations. The recovery of undegraded mucin in ileal digesta has important implications for nutritional studies: firstly because it may represent a considerable loss of endogenous amino acids and carbohydrates and secondly because it may provide insight into the effects of diets on the digestive tract itself.
\end{abstract}

KEY WORDS: mucin, ileal digesta, secretion, endogenous protein, pigs

\section{INTRODUCTION}

Mucus is a large molecular weight glycoprotein that covers the entire lumenal surface of the gastrointestinal tract. Several functions, primarily related to the protection of the underlying epithelium, have been attributed to the mucus layer (Neu- 
tra and Forstner, 1987; Turnberg, 1987; Lamont, 1992). Mucus, together with bicarbonate, protects the epithelium from vigorous digestive processes and corrosive gastric juices by creating an unstirred layer and by acting as a diffusion barrier, preventing large molecular weight compounds (such as proteolytic enzymes) from reaching the epithelium. Mucus traps toxins and bacteria preventing infection. Adherent mucus, along with soluble mucus in the intestinal lumen, acts as a lubricant providing protection from mechanical damage caused by the passage of food. In addition, mucus also plays an important role in the digestive processes by creating a digestive zone in which enzymes are immobilized near the epithelial surface, preventing their rapid removal by peristalsis and placing them in a more favourable position for digestion. As such, mucus is exposed to all chemical and physical forces of digestion. Allen (1981) proposed that proteolysis, augmented by physical abrasion, is the primary reason for the presence of mucus in the lumen of the digestive tract. In addition, evidence suggests that, once in the intestinal lumen, little degradation of mucus occurs prior to the large intestine where it is fermented by enteric bacteria (Hoskins, 1984). The recovery of undegraded mucin in ileal digesta has generated a great deal of interest from a nutritional point of view since it could represent a considerable proportion of endogenous protein and carbohydrate recovered at the distal ileum.

Endogenous protein originates from digestive enzymes (salivary, pancreatic and mucosal), gastric, intestinal and bile secretions, and sloughed epithelial cells. Many reviews on endogenous protein can be found in the literature (e.g., Low, 1982a; Souffrant, 1991; Nyachoti et al., 1997). Endogenous nitrogen derived from gastrointestinal mucosa is particularly important since it is estimated to represent 64 to $83 \%$ of the total daily amount of endogenous nitrogen entering the lumen of the digestive tract (Low, 1982a; Souffrant, 1991). This observation is consistent with the high metabolic activity of the mucosa. Approximately $43 \%$ of whole body protein synthesis occurs in the liver and gastrointestinal tract, despite the fact that these organs represent only 14\% of whole body protein (McNurlan and Garlick, 1980). Consistent with its secretory role, the rates of protein synthesis in mucosa are twice that in serosa (Garlick et al., 1980; Attaix and Arnal, 1987). While McNurlan et al. (1979) suggested that as much as $50 \%$ of protein synthesized in jejunal mucosa might be attributed to replacement of lost epithelial cells, DaCosta et al. (1971) reported that only 8 to $15 \%$ of protein lost from the small intestine was derived from this source. In addition, while 70 to $80 \%$ of endogenous nitrogen is estimated to be reabsorbed (Low, 1982a; Souffrant et al., 1986; Krawielitzki et al., 1990), little digestion of mucin occurs prior to the large intestine (Hoskins, 1984). These data, which are supported by observations from digestibility trials, point to mucin as an important source of endogenous protein. The presence of mucin in ileal digesta, because of its high threonine, serine and proline contents (Scawen and Allen, 1977; Mantle and Allen, 1981), has often been implicated in 
the predominance of these amino acids in endogenous protein (e.g., Sauer et al., 1977) and thus their relatively low apparent ileal digestibilities in diets for pigs which is often reported in the literature (Sauer and Ozimek, 1986). In addition, fermentation of mucin by bacteria in the large intestine would explain the considerably large intestinal disappearance of these amino acids, particularly threonine (Sauer and Ozimek, 1986).

The objective of this review is to present current knowledge regarding the effects of diets and dietary ingredients on the secretion of mucus from the gastrointestinal mucosa and its subsequent recovery in ileal digesta and faeces. For more comprehensive discussions of mucus structure, function and physiology, readers are directed to several previous reviews (Allen, 1981, 1984; Allen et al., 1984, 1993; Forstner and Forstner, 1986; Neutra and Forstner, 1987; Mantle and Allen, 1989; Lamont, 1992).

\section{STRUCTURE OF MUCUS}

Adherent mucus gels are comprised of large molecular weight glycoproteins, $2 \times 10^{6}$ daltons, called mucins. Mucins consist of four subunits, weighing approximately $5 \times 10^{5}$ daltons each, that are linked by disulphide bonding and are arranged into the 3-dimensional polymeric structure necessary for gel formation. Mercaptoethanol- or proteolytically-reduced glycoprotein subunits lack gel-forming properties (Allen et al., 1984; Bell et al., 1985; Pearson et al., 1986). Two different models have been proposed for the polymeric structure of mucin. Allen et al. (1981) proposed a four bladed windmill structure in which the protein backbones of all four mucin subunits are linked in a common nonglycosylated region. Carlstedt and Sheehan (1984) proposed that mucin resembles a 'coiled thread': a long peptide containing several glycosylated and nonglycosylated regions. Mucin polymers overlap and are joined noncovalently to provide the structural basis of the gel. These noncovalent interactions are strong enough to resist osmotic pressure and solubilization, but not strong enough to resist gel spreading or mechanical disruption (Bell et al., 1985). Mucus gels are filled with large volumes of water, up to $95 \%$ by weight, and organic constituents such as lipids, proteins, ions, and enzymes that are probably acquired from epithelial secretions and exfoliated and disrupted cells (Neutra and Forstner, 1987). Contaminant materials, including lipids and proteins, strengthen mucus gels making these more resistant to proteolysis (Slomiany et al., 1984; Lee et al., 1987; Sellers et al., 1991).

Mucins are characterized by high carbohydrate, typically over $80 \%$ of dry weight, and relatively low protein, 15 to $20 \%$, contents (Table 1 ). The protein backbone of mucins is surrounded by oligosaccharide chains and resembles a 'bottle-brush' structure (Allen, 1981). The protein core is divided into at least two distinct re- 
gions. The glycosylated region of the mucin molecule, representing more than $95 \%$ of the glycoprotein, is termed ,native" mucin. Protein in this region accounts for approximately $65 \%$ of the total protein of mucin and is rich in serine, threonine and proline, which make up 40 to $70 \mathrm{~mol} / 100 \mathrm{~mol}$ of the native mucin amino acids (Table 1). Threonine and serine provide attachment sites for the oligosaccharide chains while proline may play a role in maintaining a particular conformation in the protein core, allowing carbohydrate chains to be packed very closely (Forstner and Forstner, 1986). It was suggested that in pig gastric mucin one in every three or four amino acids carry a carbohydrate chain (Allen, 1981). The tight packing of oligosaccharides makes this region relatively resistant to proteolytic attack. The second region, based on its accessibility to proteolytic attack, is the nonglycosylated or ,naked" region, which represents about $35 \%$ of mucin protein or 4 to $5 \%$ of the total glycoprotein. This region has an amino acid composition similar to that of

TABLE 1

The composition of native and pronase-digested gastric and small intestinal mucins from pigs

\begin{tabular}{|c|c|c|c|c|c|c|c|}
\hline \multirow{2}{*}{ 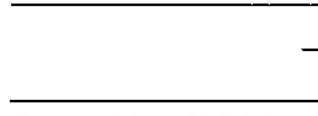 } & \multicolumn{3}{|c|}{ Gastric } & \multicolumn{3}{|c|}{ Intestinal } & \multirow{2}{*}{$\begin{array}{l}\text { Crude } \\
\text { Mucinu }\end{array}$} \\
\hline & Native ${ }^{2}$ & \multicolumn{2}{|c|}{ Pronase $^{z}$} & Native $^{x}$ & \multicolumn{2}{|c|}{ Pronasew } & \\
\hline & & & & & & & \\
\hline carbohydrate & 78.0 & 82.1 & & 54.1 & 63.6 & & \\
\hline protein & 15.4 & 11.4 & & 21.2 & 15.1 & & \\
\hline sialic acid & 2.9 & 2.9 & & 21.6 & 17.5 & & \\
\hline sulphate & 3.7 & 3.7 & & 3.1 & 3.8 & & \\
\hline \multicolumn{8}{|c|}{ Amino acid composition, $\mathrm{mol} / 100 \mathrm{~mol}$} \\
\hline threonine & 18.3 & 25.3 & & 27.2 & 34.8 & & 15.7 \\
\hline serine & 18.1 & 26.1 & & 12.1 & 15.5 & & 12.0 \\
\hline proline & 16.0 & 18.5 & & 16.4 & 21.0 & & 12.5 \\
\hline remainder & 47.6 & 30.1 & & 44.3 & 28.7 & & 59.8 \\
\hline \multicolumn{8}{|c|}{ Carbohydrate composition, $\mathrm{mol} / 100 \mathrm{~mol}$} \\
\hline fucose & 17.4 & 16.9 & $15.5^{y}$ & 9.6 & 14.0 & $10.5^{\mathrm{v}}$ & 14.7 \\
\hline galactose & 39.9 & 40.2 & $36.1^{y}$ & 26.5 & 29.5 & $27.6^{v}$ & 29.9 \\
\hline GlcNAc & 29.9 & 29.1 & $35.3^{y}$ & 22.6 & 19.6 & $28.9^{\mathrm{y}}$ & 24.4 \\
\hline GalNAc & 12.8 & 13.8 & $13.1^{y}$ & 41.3 & 36.9 & $32.9^{v}$ & 31.0 \\
\hline GlcNAc/GalNAc ratio & 2.3 & 2.1 & 2.7 & 0.6 & 0.5 & 0.9 & 0.8 \\
\hline $\begin{array}{l}\text { Scawen and Allen (19) } \\
\text { Stanley et al. (1983) } \\
\text { × Mantle and Allen (198 } \\
\text { " Mantle et al. (1981) } \\
\text { Choi et al. (1991) } \\
\text { Cien et al. (1997) }\end{array}$ & & & & & & & \\
\hline
\end{tabular}


an average globular protein, but is particularly enriched in cysteine, consistent with its role in the formation of the polymeric structure of mucus via the joining of mucin subunits by disulphide bridges. A third region, the link region, has also been identified (Neutra and Forstner, 1987; Mantle and Allen, 1989).

The carbohydrate fraction consists of galactose, fucose, $\mathrm{N}$-acetylgalactosamine (GalNAc), N-acetylglucosamine (GIcNAc) and sialic acid. These are arranged into linear or branched oligosaccharide chains, varying in length from two to twenty-two sugars and are always linked (O-glycosidically) via GalNAc to the hydroxyl group of either serine or threonine in the protein core. Chain elongation occurs by alternating GlcNAc and galactose. In gastric mucin, chain elongation from GalNAc begins with galactose whereas in the small intestine it starts with GlcNAc. Branches develop by glycosidic bonding of GlcNAc to either galactose or core GalNAc. Sialic acid and fucose are always found in the terminal position at the nonreducing ends of main or branched chains. The arrangement of terminal oligosaccharides specify the $\mathrm{ABH}$ antigens of the $\mathrm{ABO}$ blood group system. Chains ending in GalNAc are type A, those ending in galactose type $B$ and those terminating in fucose $\alpha 1-2$ galactose type $\mathrm{H}$. Acidity of mucin glycoproteins are conferred by sialic acid, approximately 2 and $18 \%$ in gastric and intestinal mucin, respectively, and sulphate, 3 to $5 \%$ of the glycoprotein. Gastric mucins have longer carbohydrate chains than intestinal mucins, approximately 19 compared to 8 carbohydrate residues per chain. As a result, gastric mucins have a higher carbohydrate content and the two mucins differ markedly in carbohydrate composition. In pigs, gastric mucins have higher galactose and GlcNAc and lower GalNAc contents (Table 1). In humans, these differences are not so obvious (Table 2). In addition to these gross differences, there are also differences based on charge (e.g., Stanley et al., 1983; Wesley et al., 1983) and regional differences in composition within each of the areas of the gastrointestinal tract (e.g.,

TABLE 2 Selective carbohydrate composition ( $\mathrm{mol} / 100 \mathrm{~mol})$ of human gastric and intestinal mucins presented by blood group and the composition of mucin carbohydrate in ileal effluent

\begin{tabular}{lcccccc}
\hline & \multicolumn{3}{c}{ Gastric $^{2}$} & \multicolumn{2}{c}{ Intestinaly $^{*}$} & \multirow{2}{*}{ Ileal effluent $^{\mathrm{x}}$} \\
& $\mathrm{A}$ & $\mathrm{O}$ & $\mathrm{B}$ & $\mathrm{A}$ & $\mathrm{H}$ & \\
\hline Fucose & 25.6 & 24.5 & 22.1 & 25.5 & 29.6 & 17.7 \\
Galactose & 34.5 & 37.2 & 40.3 & 24.3 & 31.8 & 38.9 \\
GlcNAc & 25.9 & 27.9 & 26.6 & 24.0 & 26.5 & 33.1 \\
GalNAc & 14.1 & 10.4 & 11.0 & 26.2 & 12.1 & 10.2 \\
& & & & & & \\
GlcNAc/GalNAc ratio & 1.8 & 2.7 & 2.4 & 0.9 & 2.2 & 3.2 \\
\hline
\end{tabular}

"Schrager and Oats (1974), detcrmined by blood group specificity

y Mantle et al. (1984), determined by blood group specificity

${ }^{x}$ Lien et al. (1996) 
Ohara et al., 1993; Karlsson et al., 1997; Nordman et al., 1997, 1998). As well, the extent of completeness of the oligosaccharide chains and the number of chains per molecule vary (Allen, 1981, 1984).

\section{DEGRADATION OF MUCUS IN THE STOMACH AND SMALL INTESTINE}

The mucus gel is not static, it is a dynamic balance between erosion and secretion. Several in vitro studies have demonstrated the proteolytic digestion of mucin into component subunits by pepsin, pronase, papain and trypsin (Scawen et al., 1977; Pearson et al., 1980; Mantle et al., 1981; Laszewicz et al., 1985; Lee et al., 1987). Similar results were obtained in in vivo studies. Allen et al. (1980) investigated the effects of peptic digestion of mucus by analyzing the relative amounts of pepsin-degraded (low molecular weight subunits) and native mucin glycoprotein in human gastric washouts. While 68 and $73 \%$ of mucin in the washouts, following stimulation by pentagastrin and insulin, repectively, were degraded, mucin obtained by scraping the mucosa of gastrectomy patients was degraded by only $21.2 \%$. Mucus acquired by scraping the stomach and intestine of gastric and duodenal ulcer patients contained high amounts of degraded glycoprotein, 65.1 and $50.2 \%$, respectively, compared to $33.4 \%$ in pancreatoduodenectomy patients, although there were no differences in the total amount of glycoprotein between the three groups (Younan et al., 1982). Sellers et al. (1989) demonstrated a correlation between the extent of polymerization of mucins and the strength and stability of mucus gels. Allen et al. (1990) illustrated this relationship in the context of the mucus gel in ulceration, indicating that proteolytic degradation weakens mucus gels, making these more susceptible to the physical forces of digestion. The introduction of pepsin into the stomach of rats caused a linear increase in the recovery of mucin up to a pepsin concentration of $1 \mathrm{mg} / \mathrm{mL}$ (Munster et al., 1987). There were no differences in mucin outputs as the pepsin concentration was increased from 1 to $2 \mathrm{mg} / \mathrm{mL}$. Addition of a 10 -fold excess of bovine serum albumin to the stomach resulted in a $60 \%$ reduction in the effect of pepsin on glycoprotein recovery (Munster et al., 1987). Furthermore, peptic degradation of mucus is reduced in the presence of ethanol, a pepsin denaturant (Laszewicz et al., 1985). Incubation of radioactive- labeled intestinal mucus glycoprotein in the upper and lower small intestine for up to $3 \mathrm{~h}$ resulted in a decrease in viscosity as degradation to mucin subunits took place (Ofosu et al., 1978). In that study, the recovery of the label was 70 to $90 \%$ suggesting that little absorption of degradation products occurred. Similar results were obtained for pancreatectomized rats leading these authors to suggest that limited degradation of mucus by epithelial enzymes might be a mechanism by which local control over the thickness of the mucus layer could be achieved. Bandurko et al. (1984) proposed that degradation of adherent mucus is necessary 
to facilitate the transport of materials through the gel layer. In the absence of pancreatic proteases there is a reduction in the tumover rate of many large molecular weight proteins of the intestinal brush border (Alpers, 1984), further demonstrating a role for lumenal proteases in regulating mucosal protein synthesis.

Increased pepsin concentration is positively correlated with glycoprotein output (Allen et al., 1980; Munster et al., 1987) and the amount of degraded subunits (Allen et al., 1980; Laszewicz et al., 1985). It is, therefore, proposed that proteolytic enzymes continuously erode mucus gels throughout the gastrointestinal tract. Proteolysis is associated with a loss of amino acids ( 20 to $30 \%$ ), except for threonine, serine and proline, and little $(<1 \%)$ or no loss of carbohydrate (Table 1$)$. Total recovery of mucin is greater than $95 \%$. Exhaustive proteolysis is without further effect (Mantle et al., 1981; Lee et al., 1987). The oligosaccharide chains, therefore, protect the protein of native mucin making it resistant to further proteolysis until their removal. According to Hoskins (1981) and Variyam and Hoskins (1983) at least $50 \%$ of the carbohydrates must be removed before any degradation of native protein occurs. The carbohydrate composition of mucin in ileal effluent from ileostomates suggests that some degradation of mucin oligosaccharide chains occurs prior to the large intestine (Lien et al., 1997). Compared to mucins obtained from either the stomach or small intestine, mucin in ileal effluent have lower fucose $(17.7 \mathrm{vs}$ 22.1 to $29.6 \mathrm{~mol} \%$ ) and higher GlcNAc (33.1 vs 24.0 to $27.9 \mathrm{~mol} \%$ ) contents (Table 2). Alternatively, these differences could result from incomplete synthesis of oligosaccharide chains as a result of increased mucin secretion (Forstner et al., 1984; Ohara et al., 1984). Forstner et al. (1984) noted an increase in the proportions of galactose and GlcNAc, at the expense of fucose and GalNAc, concomitant with a five- to eight-fold increase in mucin secretion from rat small intestinal rings exposed to cholera toxins for up to $4 \mathrm{~h}$. These data support the proposition that at elevated levels of mucus synthesis, mucin oligosaccharide chain elongation may be incomplete, with mucin secreted in an immature state (Allen, 1981, 1984; Forstner et al., 1984). Terminal sugars would be most affected resulting in lower contents of fucose, galactose and GalNAc. The composition of mucin carbohydrates in ileal effluent (Table 2) is, however, within the range of values reported by Westley et al. (1983). Neither bile (Allen et al., 1984; Bell et al., 1985) nor luminal acid (Bell et al., 1985) appear to affect mucus degradation. It is assumed, therefore, that mucin subunits are largely undigested until they reach the large intestine (Variyam and Hoskins, 1983; Hoskins, 1984; Forstner and Forstner, 1986).

Mucin in ileal effluent is expected to consist of a mixture of gastric and intestinal mucins. The relative proportions from these sources will be determined by the type of diet consumed. Mucin in ileal digesta from pigs fed a protein-free diet was derived largely (approximately 75\%) from the small intestine (Lien et al., 1997 ) while gastric and intestinal mucin were present in similar amounts (45 to $50 \%$ gastric mucin) in ileal digesta from pigs fed a wheat diet without or with 
added pea fibre (Lien, 1995). Feeding bean-containing diets resulted in a much higher contribution of gastric to total mucin in ileal digesta compared to pigs fed pea- or lentil-containing diets (89.4 vs 47.6 to $54.9 \%$; Table 3) (Lien and Sauer, 2000). In addition, mucin in ileal digesta is of low solubility, 20 to $40 \%$ (Clamp and Gough, 1991; Lien, 1995; Lien et al., 1997). The solubility of mucin is influenced, among other factors, by bile (Allen et al., 1984; Bell et al., 1985) and luminal pH (Bell et al., 1985). Furthermore, the protein status of the animal, probably via an effect on proteolysis of mucin (the breakdown of mucin to its component subunits increases the solubility of mucin), may also influence the solubility of mucin in ileal digesta. Soluble mucin was $24 \%$ higher in amino acid-compared to saline-infused pigs fed a protein-free diet, while total mucin output was only $6 \%$ higher (Lien et al., 1997).

TABLE 3

Ileal and faecal amino sugar recoveries and ileal mucin recovery in pigs fed barley or barley-legume $\operatorname{dicts}^{2}, \mathrm{~g} / \mathrm{d}$

\begin{tabular}{|c|c|c|c|c|c|c|}
\hline & Barley & $\begin{array}{l}\text { Barley- } \\
\text { SS7 peas }\end{array}$ & $\begin{array}{l}\text { Barley- } \\
\text { field peas }\end{array}$ & $\begin{array}{l}\text { Barley- } \\
\text { lentils }\end{array}$ & $\begin{array}{l}\text { Barley- } \\
\text { beans }\end{array}$ & SEM \\
\hline \multicolumn{7}{|l|}{ lleal amino sugars } \\
\hline $\mathrm{N}$-acetylgalactosamine & $1.12^{\mathrm{b}}$ & $1.51^{\mathrm{a}}$ & $1.17^{\mathrm{b}}$ & $1.21^{\mathrm{b}}$ & $1.56^{\mathrm{a}}$ & 0.069 \\
\hline N-acetylglucosamine & $2.06^{\mathrm{c}}$ & $2.64^{\mathrm{b}}$ & $2.04^{\mathrm{c}}$ & $2.21^{\mathrm{c}}$ & $4.17^{i}$ & 0.106 \\
\hline \multicolumn{7}{|l|}{ Ileal mucin ${ }^{y}$} \\
\hline total & $7.77^{\mathrm{c}}$ & $9.70^{\mathrm{b}}$ & $7.15^{\circ}$ & $7.42^{\mathrm{c}}$ & $14.01^{\mathrm{a}}$ & 0.478 \\
\hline gastric & $4.94^{\mathrm{b}}$ & $5.33^{\mathrm{h}}$ & $3.40^{\circ}$ & $3.64^{\mathrm{c}}$ & $12.53^{4}$ & 0.396 \\
\hline intestinal & $2.83^{\mathrm{b}}$ & $4.37^{3}$ & $3.75^{\mathrm{a}}$ & $3.78^{\mathrm{a}}$ & $1.48^{\mathrm{c}}$ & 0.135 \\
\hline \multicolumn{7}{|l|}{ Faecal amino sugars } \\
\hline $\mathrm{N}$-acetylgalactosamine & $0.43^{c}$ & $0.52^{\text {be }}$ & $0.50^{\mathrm{br}}$ & $0.60^{\mathrm{b}}$ & $0.69^{3}$ & 0.026 \\
\hline $\mathrm{N}$-acetylglucosamine & $0.84^{\mathrm{b}}$ & $1.04^{b}$ & $0.97^{b}$ & $0.99^{\mathrm{b}}$ & $1.52^{\mathrm{a}}$ & 0.051 \\
\hline
\end{tabular}

2 Lien and Sauer (2000)

${ }^{y}$ estimated from the GlcNAc/GalNAc ratio in crude mucin and the daily output of GalNAc in ileal digesta according to procedures outlined by Lien et al. (1997). All mucin in ileal digesta was assumed to be undegraded (native mucin)

are means in the same row with different superseript letters differ $(\mathrm{P}<0.05)$

\section{DEGRADATION OF MUCIN IN THE LARGE INTESTINE}

The degradation of mucin occurs largely by bacterial fermentation in the large intestine (Hoskins, 1984). Clamp and Gough (1991) reported that, while glycoprotein represented about $15 \%$ of dry matter in ileostomy effluent, only traces were 
found in faeces. Analysis of the lumenal contents of the ileum and large intestine of humans revealed differences in mucin constituents indicative of microbial fermentation in the large intestine (Vercellotti et al., 1977). These observations are consistent with the high content of mucin glycoproteins found in caecal digesta from germ-free but not conventional rats (Lindstedt et al., 1965; Hoskins and Zamcheck, 1968). Prizont and Konigsberg (1981) demonstrated fermentation of glycoproteins obtained from faeces of germ-free rats in supernatants from the caecum of coventional rats.

Variyam and Hoskins (1981) incubated hog gastric mucin in human faecal extracts and in anaerobic faecal cultures. They reported that after $48 \mathrm{~h}$ only 65 to $90 \%$ of mucin carbohydrates and 30 to $50 \%$ of mucin protein were degraded in faecal extracts while in anaerobic cultures 89 to $99 \%$ of the sugars and 20 to $81 \%$ of protein were degraded. After $96 \mathrm{~h}$ of incubation in two faecal cultures between 40 and $50 \%$ of mucin protein and 93 to $97 \%$ of mucin carbohydrates were fermented (Variyam and Hoskins, 1983). In another study (Miller and Hoskins, 1981) mucin hexose degradation exceeded $90 \%$ in more than half of the faecal cultures while mean protein degradation was only $65 \%$ after $48 \mathrm{~h}$ incubation.

$A$ variety of glycosidases, produced exclusively by enteric bacteria, are required for the complete degradation of mucin oligosaccharide chains. These enzymes are primarily extracellular exoglycosidases that cleave terminal monosaccharides one at a time from the nonreducing end of oligosaccharide chains. A high degree of substrate specificity is determined by the monosaccharide to be removed, its anomeric configuration and the location of its glycosidic linkage to the next sugar (Hoskins, 1984). Evidence from Hoskins et al. (1983) and Bayliss and Houston (1984) indicate that a combination of bacterial species, each having a different set of enzymes, may be required for complete degradation of mucin glycoproteins. However, of the many different kinds of bacteria found in faeces only a small proportion, approximately $1 \%$, are capable of degrading mucin glycoproteins (Miller and Hoskins, 1981; Bayliss and Houston, 1984; Stanley et al., 1986). These data support the premise that little, if any, digestion of mucin occurs prior to the large intestine.

CONTRIBUTION OF MUCIN TO ENDOGENOUS PROTEIN AND CARBOHYDRATE

Results from several studies indicate that mucin is the primary source of endogenous carbohydrates in ileal effluent. Mucin represents the majority of carbohydrate in canine Heidenhain pouches (Kowalcwski et al., 1976). Englyst and Cummings $(1986,1987)$ reported that fucose and galactose represented about $65 \%$ of the total neutral carbohydrates in ileostomy effluent from humans consuming 
nonstarch polysaccharide-free diets. Mucin carbohydrates, namely galactose, fucose and amino sugars, accounted for $77 \%$ of the total carbohydrates at the distal ileum of colectomized rats fed fibre-free diets (Monsma et al., 1992). More recently, it was reported that fucose, galactose, GalNAc, and GlcNAc represent more than $90 \%$ of total carbohydrate in the water-soluble, ethanol-precipitable fraction of ileal digesta from pigs fed a protein-free diet (Lien et al., 1997). In the aforementioned study, mucin represented approximately $74,75,53$, and $100 \%$ of fucose, galactose, GlcNAc and GalNAc in ileal digesta, respectively. The low contribution of GlcNAc is probably due to the presence of proteoglycans. In ileostomates consuming increasing amounts of soya fibre more than $85 \%$ of endogenous fucose, galactose, GalNAc, and GlcNAc were derived from mucin (Lien et al., 1996). Interestingly, the outputs of endogenous carbohydrates, and thus mucin, were nearly twice as high in males compared to females.

The contribution of mucin to total endogenous protein was determined by estimating the mucin content in ileal digesta from pigs fed a protein-free diet and given either a complete amino acid mixture or saline intravenously (Lien et al., 1997). Protein in mucin represented only 5 to $11 \%$ of endogenous protein, depending on the infusion treatment and the degree of proteolytic degradation. However, the predominant amino acids in mucin, namely threonine, serine and proline, represented considerably higher proportions compared to the other amino acids, from 28 to $33 \%, 13$ to $16 \%$ and 7 to $24 \%$, respectively. It was suggested that these values might even be underestimated because of the high content of threonine in the soluble nonmucin protein fraction of digesta (Lien et al., 1997). This underestimation could result from the fact that these estimates were based on the assumption that mucin oligosaccharide chain elongation was relatively complete, whereas it is generally recognized that at elevated mucin secretions (as with consumption of food compared to fasting) there is incomplete elongation of oligosaccharide chains (Allen, 1981, 1984). These results are consistent with those obtained with protein-free diets, showing threonine to be the predominant indispensable amino acid in endogenous protein (e.g., Sauer et al., 1977). The presence of mucin in ileal digesta will, therefore, explain the low digestibilities of this amino acid in many feedstuffs fed to pigs (Sauer and Ozimek, 1986).

\section{EFFECT OF DIET ON MUCIN SECRETION}

Since mucin secretion is stimulated by many of the same neural and hormonal factors that control digestive processes (Allen, 1981; Neutra et al., 1982; Forstner and Forstner, 1986; Neutra and Forstner, 1987; Mantle and Allen, 1989), diet composition is expected to have considerable effects on mucin secretion. These effects might be indirect, via their influence on digestive processes, or direct, via their 
interaction with the mucus gel. One of the more important indirect influences would be the secretion of proteolytic enzymes, since these are also stimulated by these same secretagogues (Heresy, 1987; Solomon, 1987). Mucin output (e.g., Kowalewski et al., 1976; Allen et al., 1980) and the proportion of mucin subunits (Allen et al., 1980) is increased in the presence of pepsin following the administration of stimulants. Mantle and Allen (1989) have suggested that the effects of some of these stimulants on mucin secretion may in fact be modulated by their effect on proteolytic enzyme secretion. The results from recent studies support previous reports that mucin secretion is regulated by many of the hormonal controls governing digestive processes. Insulin (Tabuchi et al., 1997), secretin (Tani et al., 1997), and gastrin (Ichikawa et al., 1993, 1998; Komuro et al., 1999) have been implicated as stimulants for mucus secretion.

The consumption of food increases mucus synthesis. The synthesis of gastric glycoproteins is reduced in fasted rats (Dekanski et al., 1975; Ohara et al., 1984). Kowalewski et al. (1976) reported a 50\% increase in glycoprotein carbohydrate output in canine Heidenhain pouches following the consumption of a meal. This may have resulted from an increase in proteolytic degradation, since pepsin secretion was increased by $300 \%$. Reducing food intake in rats to half their normal daily consumption resulted in a dramatic decrease in the amount of immunoreactive mucin (relative to protein and DNA) in intestinal scrapings (Sherman et al., 1985). Mariscal-Landin et al. (1995) reported that the total output of hexosamines (GalNAc plus GlcNAc) in ileal digesta were 6.8 and $6.9 \mathrm{mmol} / \mathrm{kg}$ dry matter intake in pigs fed a protein-free and a low protein diet, respectively. These values increased to 10.2 to $13.1 \mathrm{mmol} / \mathrm{kg}$ dry matter intake when the pigs received high protein diets.

Few studies have examined the effects of individual dietary constituents on mucin secretion. These studies focused primarily on the effect of dietary fibre; an interesting picture is emerging. Adaptation to diets high in fibre induce structural and morphological (Vahouny and Cassidy, 1986) and cytokinetic (Jacobs, 1986) changes in the digestive tract that indicate a capacity for higher mucin secretion, i.e. more mucin-secreting cells as a result of an increase in the surface area of the intestinal tract. Indeed, total daily ileal hexosamine outputs were approximately $1.5 \mathrm{~g}$ for $35 \mathrm{~kg}$ pigs (Mariscal-Landin et al., 1995) compared to $2.8 \mathrm{~g}$ for $55 \mathrm{~kg}$ pigs (Lien et al., 1997) fed protein-free diets of similar composition. Studies measuring synthesis or amounts of mucus in sections of the gastrointestinal tract suggest a greater secretion of mucus in animals fed diets containing insoluble rather than soluble fibre. Vahouny et al. (1985) reported an increase in incorporation of ${ }^{35} \mathrm{~S}$, 150 and $264 \%$, and ${ }^{3} \mathrm{H}, 190$ and $202 \%$, into jejunal glycoproteins of rats fed diets containing $10 \%$ cellulose or $10 \%$ wheat bran, respectively, compared to rats fed a fibre-free diet. Much of this increase in radioactivity was associated with surface glycoprotein, particularly glycoprotein that was loosely associated (glycoproteins 
recovered by washing the intestine compared that that recovered after rinsing or from tissue homogenates). Interestingly, the proportion of goblet cells was significantly reduced in rats fed the cellulose-containing diet, $9.7 \%$ compared to those fed either the fibre-free and wheat bran-containing diets, 13.2 and $13.6 \%$, respectively. These results were later supported by Satchithanandan et al. (1989). In the aforementioned study, immunoreactive mucin in the lumen of the small intestine of rats fed a diet containing $10 \%$ wheat bran was $210 \%$ higher than in rats fed a fibre-free dict. The amounts of total immunoreactive mucin (lumenal plus tissue) were 230 and $200 \%$ higher in rats fed diets containing 10 and $20 \%$ wheat bran, respectively, compared to the fibre-free controls. The amount of lumenal immunoreactive mucin (acquired by aspiration of the mucosal surface) was higher, approximately 350 and $200 \%$, in the stomach and small intestine, respectively, of rats fed a diet containing $5 \%$ citrus fibre, compared to those fed a fibre-free diet (Satchithanandan et al., 1990). However, there was no effect on the amount of lumenal immunoreactive mucin in any section of the gastrointestinal tract when the diet contained $5 \%$ guar gum. There was no effect either on the amount of immunoreactive mucin in gastric, small intestinal, and colonic tissues of rats fed a diet containing $5 \%$ citrus fibre. Satchithanandan et al. (1990) reported that the soluble fibre carrageenan also had no effect on the amount of small intestinal mucin.

More recent studies, however, suggest an opposite effect. Increasing amounts of pea fibre $(0,80,160$ and $240 \mathrm{~g} / \mathrm{day})$ were fed to pigs in addition to $1600 \mathrm{~g} / \mathrm{day}$ of a wheat diet (Lien, 1995). Although there were no differences $(P>0.05)$ in ileal recoveries of mucin between diets, there was a linear trend $(P=0.088)$ towards an increase with increasing pea fibre consumption (Table 4). Exclusion of results from one pig, which were quite variable, resulted in a linear increase $(P<0.05)$ in mucin output with increasing fibre intake. The mucin recoveries were 6.1,6.9,7.3, and $7.8 \mathrm{~g} /$ day for diets supplemented with $0,80,160$, and $240 \mathrm{~g}$ pea fibre/day, respectively. The ileal recoveries of total hexosamines increased linearly from approximately 3.5 to $7.5 \mathrm{mmol} / \mathrm{kg}$ dry matter intake per day in pigs fed proteinfree diets containing 17,34, and $102 \mathrm{~g}$ crude fibre $/ \mathrm{kg}$ diet from wood cellulose, maize cobs, and wheat straw (Mariscal-Landin et al., 1995). Monsma et al. (1992) reported a $34 \%$ increase in mucin carbohydrate output in colectomized rats fed a diet containing $5 \%$ gum arabic compared to a fibre-free diet.

Observations that mucus secretion is elevated by insoluble but not soluble fibre are in contrast to those of Cassidy et al. (1981) who reported that feeding diets supplemented with either $15 \%$ pectin or lucerne to rats increased the percentage of intestinal villi exhibiting structural deviations by about $300 \%$ compared to rats fed chow. Neither $15 \%$ wheat bran nor cellulose appeared to have any cffect on intestinal morphology. There was, however, a visual increase in adherent mucus and an apparent increase in goblet cell activity. The intestine responds to the consumption of soluble fibre such as guar gum and pectin by increasing crypt cell production 
TABLE 4 Recoveries (g/d) of amino sugars in ileal digesta and faeces and total, gastric, and intestinal mucin in ileal digesta of pigs consuming either a protein-free diet or diets with increasing amounts of pea fibre supplemented to a wheat diet

\begin{tabular}{|c|c|c|c|c|c|c|}
\hline & \multirow{2}{*}{$\begin{array}{c}\text { Protein- } \\
\text { free }^{2}\end{array}$} & \multicolumn{5}{|c|}{ Pea fiber intake, $g / d^{y}$} \\
\hline & & 0 & 80 & 160 & 240 & SEM \\
\hline \multicolumn{7}{|l|}{ Ileal amino sugars } \\
\hline $\mathrm{N}$-acetylgalactosamine & $1.12 \pm 0.30^{x}$ & 1.03 & 1.19 & 1.10 & 1.31 & 0.056 \\
\hline $\mathrm{N}$-acetylglucosamine & $1.72 \pm 0.68$ & 1.98 & 2.45 & 2.30 & 2.68 & 0.079 \\
\hline \multicolumn{7}{|l|}{ Ileal mucinw } \\
\hline total & $5.80 \pm 1.49$ & 6.18 & 7.25 & 6.76 & 7.78 & 0.469 \\
\hline gastric & $1.45 \pm 0.61$ & 2.82 & 3.46 & 3.34 & 3.42 & 0.224 \\
\hline intestinal & $4.35 \pm 1.11$ & 3.38 & 3.80 & 3.42 & 4.58 & 0.322 \\
\hline \multicolumn{7}{|l|}{ Faecal amino sugars } \\
\hline $\mathrm{N}$-acetylgalactosamine & & 0.30 & 0.43 & 0.49 & 0.63 & 0.016 \\
\hline $\mathrm{N}$-acetylglucosamine & & 0.63 & 0.97 & 1.10 & 1.41 & 0.027 \\
\hline \multicolumn{7}{|l|}{${ }^{2}$ Lien et al. (1997) } \\
\hline \multicolumn{7}{|l|}{ Lien (1995) } \\
\hline \multicolumn{7}{|l|}{ mean $\pm \mathrm{SD}$} \\
\hline w estimated from the Glc & GalNAc ratio & crude & in and $t$ & aily ou & of Gall & $\mathrm{c}$ in ileal \\
\hline
\end{tabular}

rates (Jacobs, 1986; Johnson and Gee, 1986), presumably in response to the degree of damage as was reported by Cassidy et al. (1981). Similar increases in crypt cell production were not observed when oat bran was fed (Jacobs, 1983). Although Vahouny et al. (1985) did observe an increase in crypt cell proliferation and migration in the jejunum of rats fed a diet supplemented with wheat bran, Jacobs and White (1983) did not observe any effect of wheat bran. Crypt cell production rates increased in response to local cell damage (Rijke et al., 1976). These data, together with those presented for mucus secretion and output, give an indication of the effects of these different types of fibre in the gastrointestinal tract and mucosal response. It appears that insoluble fibre has a more abrasive action, scraping mucin from mucosa as they pass through the digestive tract. This abrasive action was demonstrated in a study by Lien et al. (1996) with ileostomates. Human ileostomates were given graded levels of soya fibre, from 1.1 to $33.7 \mathrm{~g} / \mathrm{day}$. While there was no relationship between daily outputs of GlcNAc and GalNAc and fibre intake, the outputs of these sugars increased linearly with increasing effluent dry matter output. In animals fed diets containing insoluble fibre the mucus layer may be maintained by increasing goblet cell activity and thus increasing the capacity 
for mucin synthesis. This increase in goblet cell activity might account for the higher amounts of adherent mucus and increased incorporation of labels observed in previous studies with insoluble fibre (Vahouny et al., 1985; Satchithanandan et al., 1989, 1990). Soluble fibre, on the other hand, is far more damaging to the intestinal mucosa which must respond by re-establishing both the mucus and epithelial layers. The epithelial layer is repaired by increasing the rate of cell replacement. The mucus layer may be re-established primarily using mucin stored in crypt cells rather than by increased mucin synthesis. These changes may not be detected in isotope studies because mucin, that is stored, will not be labeled and because rats are fasted for $24 \mathrm{~h}$ prior to measurements, allowing the intestine sufficient time to repair itself (Silen and Ito, 1985). Since the amount of mucin in the mucus layer represents a balance between secretion and erosion, a measurement of both is necessary to obtain a more complete insight into the dynamic state of the mucus layer (Mantle and Allen, 1989).

In addition to these direct physical effects of fibre, secondary effects may also play a role in changes in mucin output. Although the activities of proteolytic enzymes in pancreatic juice do not appear to be influenced by diet (e.g., Low, 1982b; Żebrowska et al., 1983), studies by Schneeman et al. (1982) indicate that diets supplemented with different types of fibre affect the activities and distribution of proteolytic enzymes in the intestinal lumen that may influence the degradation of mucus gels. Trypsin and chymotrypsin activities were higher in intestinal contents and lower in mucosal homogenates of rats fed a diet containing wheat bran compared to a fibre-free diet (Schneeman et al., 1982). However, for pectin, enzyme activities were higher in mucosal homogenates and lower in intestinal contents (Forman and Schneeman, 1980). Guar gum increases total protease activity in the intestine (Poksay and Schneeman, 1983). Farness and Schneeman (1982) reported that oat bran, pectin, and cellulose increased small intestinal peptidase activities in rats by 12,159 and $48 \%$, respectively. The pepsin content in duodenal digesta of pigs fed a barley-soyabean meal diet was twice that of pigs fed a purified diet (maize starch and casein) diet (Żebrowska et al., 1983), which may result from the higher fibre content of the barley-soyabean meal diet. However, the extent to which these changes in proteolytic activities contribute to changes in mucin secretion and/or the recovery of mucin in ileal digesta after feeding fibre-containing diets is yet to be determined. Improvement in the protein status of pigs, either parentally (Lien et al., 1997) or enterally (Marisal-Landin et al., 1995), appears to increase mucin output, perhaps as a result of improvements in the proteolytic capacity of the digestive tract.

Lectins have become important and powerful tools in the study and characterization of gastrointestinal glycoproteins because of their selective carbohydratebinding properties (Vecchi et al., 1987; Jauregui et al., 1991; Bals et al., 1997; Ohara et al., 1997). Conversely, Freier et al. (1985) were able to isolate lectins 
from several different plants using immobilized hog gastric mucin. The ability of lectins, which are present in variable amounts in many feedstuffs, to bind glycoproteins has important consequences in the output of mucin in the gastrointestinal tract. In addition, Haas et al. (1999) observed that some lectins can induce histamine release, suggesting a secondary modulation of mucin secretion since histamine is a known mucus secretagogue. Moreover, lectins survive digestion in the gastrointestinal tract (Begbie and Pusztai, 1989) and may facilitate the movement of mucin into the large intestine. Some of the most commonly used feedstuffs for swine, including cereals (Marsh, 1992), soyabeans and legumes in particular (Begbie and Pusztai, 1989; Jauregui et al., 1991) contain lectins that have varying capacities to bind glycoprotein. In a recent study, pigs were fed a barley, a barley-bean (c.v. Great Northern beans), a barley-lentil and two barley-pea diets (Lien and Sauer, 2000). The sources of peas were line SS7 and c.v. Trapper which are high and low in trypsin inhibitor activities, respectively. Great Northern beans are characterized by a high lectin content. Consumption of diets containing SS7 peas and beans resulted in significant increases in the recovery of mucin in ileal digesta compared to diets containing barley alone or barley and Trapper peas or barley and lentils. In the same order for these diets, the ileal recoveries of mucin were 9.70 , $14.01,7.77,7.15$, and $7.42 \mathrm{~g} /$ day, respectively (Table 3 ). The high output of mucin with the bean-containing diet is not surprising since the toxic effects of lectins are well documented (Begbie and Pusztai, 1989; Kik et al., 1989; Vander Poel, 1990). However, the relatively high output of mucin following consumption of the diet containing SS7 peas was somewhat unexpected since these peas have a higher trypsin inhibitor content than Trapper peas. Further studies are required to elucidate factors in SS7 peas, including lectins, that contribute to the higher recovery of mucin in ileal digesta. The effect of these diets on the relative proportions of gastric and intestinal mucins in ileal digesta is also of interest. Mucin in ileal digesta of pigs fed the barley diet was derived primarily from the gastric mucosa (63.6\%). The proportions of gastric and intestinal mucus in ileal digesta of pigs fed diets containing peas and lentils were similar ( 49.1 to $54.9 \%$ gastric mucin). The estimated high contribution of mucin derived from the gastric mucosa in pigs fed beans $(89.4 \%$ ) might, in part, reflect the recovery of GlcNAc from beans in ileal digesta. The diet with bcans contained approximately $0.08 \%$ GlcNAc. Gastric mucin represented approximately $25 \%$ of mucin in ileal digesta of pigs fed a protein-free diet and approximately $50 \%$ of mucin in ileal digesta of pigs fed a wheat diet, without or with added pea fibre (Table 4).

Estimates of the recovery of mucin in faeces, compared to ileal digesta, are confounded by the secretion of mucin in the large intestine and bacterial fermentation of gastric and small intestinal mucins. Furthermore, amino sugars derived from bacteria will also confound these estimates. The relative recoveries of amino sugars in ileal digesta and faeces indicate that considerable fermentation of mucin 
occurs in the large intestine (Tables 3 and 4). While the trends observed for the recovery of mucin in ileal digesta of pigs fed increasing levels of pea fibre were also evident to those for amino sugar recoveries in faeces, this was not the case for amino sugar recoveries in faeces of pigs fed legumes. Although the higher output of mucin of pigs fed the bean-containing diets is indicated by higher faecal amino sugar outputs, the difference compared to the other diets is not as great as in ileal digesta. Whereas increasing recoveries of amino sugars in ileal digesta, following the consumption of increasing amounts of pea fibre, indicate an increase in gastric and small intestinal mucin secretion, the recoveries of amino sugars in faeces might be explained by activities specific to the large intestine. Shiau and Chang (1983) reported that the specific activity and total output of mucinase in faeces of rats was negatively correlated with the availability of fermentable carbohydrate in different sources of fibre. The highest outputs of specific and total mucinase activities were observed in faeces of rats fed fibre-free and cellulose diets and lowest in rats fed the more readily fermentable fibres, carrageenan, pectin and guar gum. For more fermentable fibre, such as pectin and guar gum, the faecal output of mucinase was lower, although not significantly, with consumption of diets containing 15 vs $5 \%$ fibre. In a second study, a decrease in total and specific faecal mucinase activities was observed as the proportions of cellulose and agar (resistant to fermentation) were increased in the diet (Shiau and Ong, 1992). The highest mucinase activities were observed in faeces of rats consuming either a fibre-free or $15 \%$ agar diet, followed by those consuming a $7.5 \%$ agar $7.5 \%$ cellulose diet and finally by those consuming a $15 \%$ cellulose diet. As more readily fermentable carbohydrate enters the large intestine there is a reduction in fermentation of gastrointestinal mucins, and thus a potential increase in the recovery of mucin in faeces. In addition, shortchain fatty acids produced during fermentation of fibre in the large intestine stimulate the release of mucin from the colon (Sakata and Setoyama, 1995), augmenting the effects of fibre fermentability on faecal mucin output. It is apparent, therefore, that faecal estimates of mucin outputs are greatly influenced by the action of microbes in the large intestine. In contrast, mucin outputs at the distal ileum better reflect the net effect of diets in the stomach and small intestine in terms of both physical interactions and effects on digestive processes. These results indicate that the effect of diet on mucin secretion is better reflected by estimates obtained in ileal digesta rather than in faeces.

\section{CONCLUSIONS}

Mucus is a large molecular weight glycoprotein that provides a protective lining for the entire gastrointestinal tract. Once secreted into the intestinal lumen little degradation of mucus occurs prior to the large intestine. In this respect lume- 
nal mucin adds an extra level of protection by acting as a lubricant. The recovery of undegraded mucin in ileal digesta can provide important insights into the effects of diets and dietary constituents on the gastrointestinal tract. In addition, measurement of the recovery of mucin in ileal digesta provides information for the assessment of the recovery of endogenous protein to determine true digestibility. As such, there is growing interest in elucidating dietary factors that influence gastric and intestinal mucus secretion and recovery in ileal digesta. While it is apparent that dietary constituents such as fibre and lectins can have a direct effect on mucus secretion, it is also important to consider indirect effects and their consequences to the mucus layer.

\section{REFERENCES}

Allen A., 1981. Structure and function of gastrointestinal mucus. In: L. R. Johnson (Editor). Physiology of the Gastrointestinal Tract. Vol. 1. Raven Press, New York, pp. 617-639

Allen A., 1984. The structure and function of gastrointestinal mucus. In: E.C. Boedeker (Editor). Attachment of Organisms to the Gut Mucosa. CRC Press, Inc., Boca Raton, FL, pp. 3-11

Allen A., Cunliffe W.J., Pearson J.P., Sellers L.A., Ward R., 1984. Studies on gastrointestinal mucus. Scand. J. Gastroenterol. 19, Suppl. 93, 101-113

Allen A., Cunliffe W.J., Pearson J.P., Venables C.W., 1990. The adherent gastric mucus gel barrier in man and changes in peptic ulceration. J. Int. Med. 228, Suppl. 1, 83-90

Allen A., Flemstrom G., Garner A., Kivilaakso E., 1993. Gastroduodenal mucosal protection. Physiol. Rev. 73, 823-857

Allen A., Hutton D.A., Pearson J.P., Sellers L.A., 1984. Mucus glycoprotein structure, gel formation and gastrointestinal mucus function. In: Mucus and Mucosa. Ciba Foundation Symposium 109. Pitman, London, pp. 137-156

Allen A., Pearson J.P., Venables C.W., 1981. The glycoprotein from human gastric mucus gel and its breakdown by pepsin. J. Physiol. 293, 30 (Abstr.)

Allen A., Pearson J.P., Venables C.W., Younan F., 1980. Measurement of the degradation of gastric mucus gel by peptic erosion in vivo. J. Physiol. 306, 40 (Abstr.)

Alpers D.H., 1984. Interaction between digestive enzymes and the brush border. In: E.C. Boedeker (Editor). Attachment of Organisms to the Gut Mucosa. Vol. II. CRC Press, Inc., Boca Raton, FL, pp. 131-135

Attaix D., Arnal M., 1987. Protein synthesis and growth in the gastrointestinal tract of the young preruminant lamb. Brit. J. Nutr. 58, 159-169

Bals R., Woeckel W., Welsch U., 1997. Use of antibodies directed against blood group substances and lectins together with glycosidase digestion to study the composition and cellular distribution of glycoproteins in the large human airways. J. Anat. 190, 73-84

Bandurko L.N., Brodskii A.A., Gal'perin Y.M., Lazarev P.I., 1984. Enzymes of the small intestinal mucus. Bull. Exp. Biol. Med. 97, 179-183

Bayliss, C.E., Houston A.P., 1984. Characterization of plant polysaccharide- and mucin-fermenting anaerobic bacteria from human feces. Appl. Environ. Microbiol. 48, 626-632

Begbie R., Pusztai A., 1989. The resistance to proteolytic breakdown of some plant (seed) proteins and their effects on nutritional utilization and gut metabolism. In: M. Fricdman (Editor). Absorption and Utilization of Amino Acids. Vol. 3. CRC Press, Boca Raton, FL, pp. 243-263 
Bell A.E., Sellers L.A., Allen A., Cunliffe W.J., Morris E.R., Ross-Murphy S.B., 1985. Properties of gastric and duodenal mucus: effect of proteolysis, disulphide reduction, bile acid, ethanol and hypertonicity on mucus gel structure. Gastroenterology 88, 269-280

Carlstedt I., Sheehan J.K., 1984. Macromolecular properties and polymeric structure of mucus glycoproteins. In: Mucus and Mucosa. Ciba Foundation Symposium 109. Pitman, London, pp. 157-172

Cassidy M.M., Lightfoot F.G., Lauretta B.S., Grau E., Story J.A., Kritchevsky D., Vahouney G.V., 1981. Effect of chronic intake of dietary fibers on the ultrastructural topography of rat jejunum and colon. Amer. J. Clin. Nutr. 34, 218-228

Choi S.H., Kornegay E.T., Eigel W.N., 1991. Characterization of small intestinal mucus glycoproteins from pigs of various ages. Comp. Biochem. Physiol. 99, 677-680

Clamp J.R., Gough M., 1991. The glycoconjugate content of human faeces and ileostomy effluents. Clin. Chim. Acta 203, 243-248

DaCosta L.R., Croft D.N., Creamer B., 1971. Protein loss and cell loss from the small-intestinal mucosa. Gut 12, 179-183

Dekanski J.B., MacDonald A., Sacra P., Parke D.V., 1975. Effects of fasting stress and drugs on gastric glycoprotein synthesis in the rat. Brit. J. Pharmacol. 55, 387-392

Englyst H.N., Cummings J.H., 1986. Digestion of the carbohydrates of banana (Musa Paradisiaca Sapientum) in the human small intestine. Amer. J. Clin. Nutr. 44, 42-50

Englyst H.N., Cummings J.H., 1987. Digestion of polysaccharides of potato in the small intestine of man. Amer. J. Clin. Nutr. 45, 423-431

Farness P.C., Schneeman B.O., 1982. Effects of dietary cellulose, pectin and oat bran on the small intestine in the rat. J. Nutr. 112, 1315-1319

Forman L.P., Schneeman B.O., 1980. Effects of dietary pectin and fat on the small intestinal contents and exocrine pancreas in rats. J. Nutr. 110, 1992-1999

Forstner J., Roomi N., Fahim R., Gall G., Perdue M., Forstner G., 1984. Acute and chronic models for hypersecretion of intestinal mucin. In: Mucus and Mucosa. Ciba Foundation Symposium 109. Pitman, London, pp. 61-71

Forstner G.G., Forstner J.F., 1986. Structure and function of gastrointestinal mucus. In: P. Desneulle, H. Sjostrom, O. Noren (Editors). Molecular and Cellular Basis of Digestion. Elsevier Science Publishers B.V. (Netherlands), pp. 125-143

Freier T., Fleischmann G., Rudiger H., 1985. Affinity chromatography on immobilized hog gastric mucin and ovomucoid. Biol. Chem. Hoppe-Seyler 366, 1023-1028

Garlick P.J., McNurlan M.A., Preedy V.R., 1980. A rapid and convenient technique for measuring the rate of protein synthesis in tissues by injection of $\left[{ }^{3} \mathrm{H}\right]$ phenylalanine. Biochem. J. 192, 719723

Haas H., Falcone F.H., Schramm G., Haisch K., Gibbs B.F., Klaucke J., Poppelmann M., Becker W.M., Gabius H.J., Schlaak M., 1999. Dietary lectins can induce in vitro release of IL-4 and IL13 from human basophils. Eur J. Immunol. 29, 918-927

Hersey S.J. 1987. Pepsinogen secretion. In: L.R. Johnson (Editor). Physiology of the Gastrointestinal Tract. Vol. 2. Raven Press, New York, pp. 947-957

Hoskins L.C., 1981. Human enteric population ecology and degradation of gut mucins. Digest. Dis. Sci. 26, 769-772

Hoskins L.C., 1984. Mucin degradation by enteric bacteria: ecological aspects and implications for bacterial attachment to gut mucosa. In: E.C. Boedeker (Editor). Attachment of Organisms to the Gut Mucosa. CRC Press, Inc., Boca Raton, FL, pp. 51-67

Hoskins L.C., Augustines M., Mckee W.B., Boulding E.T., Kriaris M., Niedemeyer G., 1983. Mucin degradation in human colon ecosystem. Isolation and properties of fecal strains that degrade 
ABH blood group antigens and oligosaccharides from mucin glycoproteins. J. Clin. Invest. 75 , 944-953

Hoskins L.C., Zamcheck N., 1968. Bacterial degradation of gastrointestinal mucins. I. Comparison of mucin constituents in the stools of germ-free and conventional rats. Gastroenterology 54 , 210-217

Ichikawa T., Ishihara K., Saigenji K., Hotta K., 1993. Stimulation of mucus glycoprotein biosynthesis in rat gastric nucosa by gastrin. Biochem. Pharmacol. 46, 1551-1557

Ichikawa T., Ishihara K., Kusakabe T., Kurihara M., Kawakami T., Takenaka T., Saigenji K., Hotta K., 1998. Distinct effects of tetragastrin, histamine, and CCh on rat gastric mucin synthesis and contribution of NO. Amer. J. Physiol. 274, 138-146

Jacobs L.R. 1983. Effects of dictary fiber on mucosal growth and cell proliferation in the small intestine of the rat: a comparison of oat bran, pectin, and guar with total fiber deprivation. Amer. J. Clin. Nutr. 37, 954-960

Jacobs L.R., 1986. Dietary fiber and gastrointestinal epithelial cell proliferation. In: G.V. Vahouny, D. Kritchevsky (Editors). Dietary Fiber: Basic and Clinical Aspects. Plenum Press, NY, pp. 211-228

Jacobs L.R., White F.A., 1983. Modulation of mucosal cell proliferation in the intestines of rats fed a wheat bran diet. Aner. J. Clin. Nutr. 37, 945-953

Jauregui H.O., Kessimian N., McMillan P.N., Nadra L., 1991. Lectin binding to glycoconjugates of the human gastric fundus. Prog. Histochem. Cytochem. 24(2), 1-55

Johnson I.T., Gee J.M., 1986. Gastrointestinal adaptation in response to soluble non-available polysaccharides in the rat. Brit. J. Nutr. 55, 497-505

Karlsson N.G., Nordman H., Karlsson H., Carlstedt 1., Gunnar G.C., 1997. Glycosylation differences between pig gastric mucin populations: a comparative study of the neutral oligosaccharides using mass spectrometry. Biochem. J. 326, 911-917

Kik M.J.L., Rojer J.M., Mouwen J.M.V.M., Koninkx J.F.J.G., van Dijk J.E., van der Hage M.H., 1989. The interaction between plant lectins and the small intestinal epithelium: a primary cause of intestinal disturbance. Vet. Quart. 11, 108-115

Komuro T., Ichikawa T., Ishihara K., Saigenji K., Hotta K., 1999. Influence of L-365, 260, a CCk-B/ gastrin receptor antagonist, on tetragastric-stimulated mucin metabolism in rat gastric mucosa. Pharmacology 59, $11-20$

Kowalewski K., Pachkowski T., Secord D.C., 1976. Mucinous secretion from canine Heidenhain pouch after stimulation with food, pentagastrin and histamine. Eur. Surg. Res. 8, 536-544

Krawielitzki K., Żebrowska T., Schadereit R., Kowalczyk J., Hennig U., Wüensche J., Herrmann U., 1990. Determination of nitrogen absorption and nitrogen secretion in different sections of the pig's intestine by digesta exchange between ${ }^{15} \mathrm{~N}$ labelled and unlabelled animals. Arch. Anim. Nutr. 40, 25-37

Lamont J.T., 1992. Mucus: The front line of intestinal mucosal defence. Ann. New York Acad. Sci. $664,190-201$

Laszewicz W., Slomiany A., Murty V.L.N., Liau Y.H., Slomiany B.L., 1985. Effect of ethanol on the peptic degradation of gastric mucus glycoprotein. Digeb. 31, 47-53

Lee S.P., Nichols J.F., Roberton A.M., Park H.Z., 1987. Effect of pepsin on partially purified pig gastric mucus and purified mucin. Cell Biol. 66, 367-373

Lien K.A., 1995. Endogenous protein in ileal digesta: Estimation of the mucin content and an evaluation of the ${ }^{15} \mathrm{~N}$-isotope dilution technique. Ph.D. Dissertation, University of Alberta, Edmonton (Canada)

Lien K.A., McBurney M.I., Beyde B.I., Thomson A.B.R., Sauer W.C., 1996. Ileal recovery of nutrients and mucin in humans fed total enteral formulas supplemented with soy fiber. Amer. J. Clin. Nutr. 63, 584-595 
Lien K.A., Sauer W.C., 2000. Nutrient digestibility and mucin output in pigs fed peas, beans (Phaseolus vulgaris), and lentils. (in preparation)

Lien K.A., Sauer W.C., Fenton M., 1997. Mucin output in ileal digesta of pigs fed a protein-free diet. Z. Ernährungswiss. 36, 182-190

Lindstedt G., Lindstedt S., Gustafsson B.E., 1965. Mucus in intestinal contents of germ-free mice. J. Exp. Med. 121, 201-214

Low A.G., 1982a. Endogenous nitrogen evaluation from absorption studies. In: Physiologie Digestive chez le Porc. Les Colloques de l'INRA, No.12. Jouy-en-Josas, Versailles, pp. 189-198

Low A.G., 1982b. The activity of pepsin, chymotrypsin and trypsin during $24 \mathrm{~h}$ periods in the small intestine of growing pigs. Brit. J. Nutr. 48, 147-159

Mantle M., Allen A., 1981. Isolation and characterization of the native glycoprotein from pig smallintestinal mucus. Biochem. J. 195, 267-275

Mantle M., Allen A., 1989. Gastrointestinal mucus. In: J.S. Davison (Ëditor), Gastrointestinal Secretion. Butterworth and Co., London, pp. 202-22.

Mantle M., Forstner G.G., Forstner J.F., 1984. Biochemical characterization of the component parts of intestinal mucin from patients with cystic fibrosis. Biochem. J. 224, 345-354

Mantle M., Mantle D., Allen A., 1981. Polymeric structure of pig small intestinal mucus glycoprotein. Biochem. J. 195, 277-285

Mariscal-Landin G., Seve B., Colleaux Y., Lebreton Y., 1995. Endogenous amino acid nitrogen collected from pigs with end-to-end ileorectal anastomosis is affected by the method of estimation and altered by dietary fiber. J. Nutr. 125, 136-146

Marsh M.N., 1992. Gluten, major histocompatibility complex, and the small intestine. A molecular and immunobiologic approach to the spectrum of gluten sensitivity ("celiac sprue»). Gastroenterology $102,330-354$

McNurlan M.A., Garlick P.J., 1980. Contribution of rat liver and gastrointestinal tract to whole-body protein synthesis in the rat. Biochem. J. 186, 381-383

McNurlan M.A., Tomkins A.M., Garlick P.J., 1979. The effect of starvation on the rate of protein synthesis in rat liver and sma!l intestine. Biochem. J. 178, 373-379

Miller R.S., Hoskins L.C., 1981. Mucin degradation in human colon ecosystem. Fecal population densities of mucin-degradation bacteria estimated by a most "probable number" method. Gastroenterology $81,759.765$

Monsma D.J., Vollendorf N.W., Marlett J.A., 1992. Determination of fermentable carbohydrate from the upper gastrointestinal tract by using colectomized rats. Appl. Environ. Microbiol. 58, 33303336

Munster D.J, Bagshaw P.F., Wilson J.G., 1987. Peptic erosion of gastric mucus in the rat. Comp. Biochem. Physiol. 87, 509-513

Neutra M.R., Forstner J.F., 1987. Gastrointestinal mucus: synthesis, secretion and function. In: L.R. Johnson (Editor). Physiology of the Gastrointestinal Tract. 2nd Edition. Raven Press, NY, pp. $975-1009$

Neutra M.R., O'Malley L.J., Specian R.D., 1982. Regulation of intestinal goblet cell secretion. II. A survey of potential secretagogues. Amer. J. Physiol. 242, G380-387

Nordman H., Davies J.R., Hermann A., Karlsson N.G., Jansson G.C., Carlstedt I., 1997. Mucus glycoproteins from pig gastric mucosa: identification of different mucin populations from the surface epithelium. Biochem J. 326, 903-910

Nordman H., Davics J.R., Carlstedt I., 1998. Mucus glycoproteins from pig gastric mucosa: different mucins are produced by the surface epithelium and the glands. Biochem. J. 331, 687-694

Nyachoti C.M., de Lange C.F.M., McBride B.W., Schultze H., 1997. Significance of endogenous gut nitrogen losses in the nutrition of growing pigs: a revicw. Can. J. Anim. Sci. 77, 149-163 
Ofosu F., Forstner J.F., Forstner G.G., 1978. Mucin degradation in the intestinc. Biochim. Biophys. Acta 543, 476-483

Ohara S., Ishihama K., Hotta K., 1993. Regional differences in pig gastric mucins. Comp. Biochem. Physiol. B. Comp. Bjochem. 106, 153-158

Ohara S., Kakei M., Ishihara K., Katsuyama T., Hotta K., 1984. Effects of fasting on mucous glycoprotein in the rat stomach. Comp. Biochem. Physiol. 79, 325-329

Ohara S., Watanabe T., Hotta K., 1997. Comparative study of carbohydrate portion of gastrointestinal mucins using enzyme-linked lectin-binding assay (ELLA). Comp. Biochen. Physiol. B. Biochem. Mol. Biol. 116, 167-172

Pcarson J.P., Allen A., Venables C., 1980. Gastric mucus: isolation and polymeric structure of the undegraded glycoprotein: its breakdown by pepsin. Gastroenterology 78, 709-715

Pearson J.P., Ward R., Allen A., Roberts N.B., Taylor W.H., 1986. Mucus degradation by pepsin: comparison of mucolytic activity of human pepsin 1 and pepsin 3 : implications in peptic ulceration. Gut 27, 243-248

Poksay K.S., Schneeman B.O., 1983. Pancreatic and intestinal response to dietary guar gum in rats. J. Nutr. 113, 1544-1549

Prizont R., Konigsberg N., 1981. Identification of bacterial glycosidases in rat caecal contents. Digest. Dis. Sci. 26, 773-776

Rijke R.P.C., Hanson W.R., Plaisier H.M., Osborne J.W., 1976. The effect of ischenic villus cell damage on crypt cell proliferation in the small intestine. Gastroenterology 71, 786-792

Sakata T., Setoyama H., 1995. Local stimulatory effect of short chain fatty acids on the mucus release from the hindgut mucosa of rats (Rattus norvegicus). Comp. Biochem. Physiol. A. Physiol. 111, 429-432

Satchithanandam S., Jahangeer S., Cassidy M.M., Flock D.K., Calvert R.J., Leeds A.R., Alabaster O., 1989. Quantitative effects of wheat bran feeding on rat intestinal mucin. FASEB J. 3, A 1066

Satchithanandam S., Vargofcak-Apker M., Calvert R.J., Leeds A.R., Cassidy M.M., 1990. Alteration of gastrointestinal mucin by fiber feeding. J. Nutr. 120, 1179.1184

Sauer W.C., Ozimek L., 1986. Digestibility of amino acids in swine: results and their practical applications. A review. Livest. Prod. Sci. 15, 367-388

Sauer W.C., Stothers S.C., Parker R.J., 1977. Apparent and true availabilities of amino acids in wheat and milling by-products for growing pigs. Can. J. Anim. Sci, 57, 775-785

Scawen M., Allen A., 1977. The action of protcolytic enzymes on the glycoprotein from pig gastric mucus. Biochem. J. 163, 363-368

Schneeman B.O., Richter B.D., Jacobs L.R., 1982. Response to dietary wheat bran in the exocrine pancreas and intestine of rats. J. Nutr. 112, 283-286

Schrager J., Oates M.D.G., 1974. The isolation and partial characterization of a glycoprotein isolated from human gastric aspirates and from extracts of gastric mucosae. Biochim. Biophys. Acta 372, 183-195

Sellers L.A., Allen A., Morris E., Ross-Murphy S.B., 1983. Rheological studies on pig gastrointestinal mucous secretions. Biochem. Soc. Trans. 11, 763-764

Sellers L.A., Allen A., Morris E., Ross-Murphy S.B., 1989. Mucus glycoprotein gels: role of glycoprotein polymeric structure and carbohydrate side-chain in gel formation. Carbohyd. Res. 178, 93-110

Sherman P., Forstner J., Roomi N., Khatri I., Forstner G., 1985. Mucin depletion in the intestine of malnourished rats. Amer. J. Physiol. 248, G418-423

Shiau S.Y., Chang G.W., 1983. Effects of dietary fiber on fecal mucinase and $\beta$-giucuronidase activities in rats. J. Nutr. [13, 138-144 
Shiau S.Y., Ong Y.O., 1992. Effects of ccllulose, agar and their mixture on colonic mucin degradation in rats. J. Nutr. Sci. Vitaminol. 38, 49-55

Silen W., Ito S., 1983. Re-epithelialization of the gastric mucosal surface. Ann. Rev. Physiol. 47, $217-229$

Slomiany A., Jozwiak Z., Takagi A., Solmiany B.L., 1984. The role of covalently bound fatty acids in the degradation of human gastric mucus glycoprotein. Arch. Biochem. Biopliys. 229, 560-567

Solomon T.E., 1987. Control of exocrine pancreatic secretion. In: L.R. Johnson (Editor). Physiology of the Gastrointestinal Tract. Vol. 2. Raven Press, New York, pp. 1173-1207

Souffrant W.B., 1991. Endogenous nitrogen losses during digestion in pigs. In: Procecdings of Vth International Symposium Digestive Physiology in Pigs. Doorwerth/Wageningen (Netherlands), pp. $147-165$

Souffrant W.B., Darcy-Vrillon B., Corring T., Laplace J.P., Kohler R., Gebhardt G., Rérat A., 1986. Recycling of endogenous nitrogen in the pig (preliminary results of a collaborative study). Arch. Anim. Nutr. 36, 269-274

Stanley R.A., Lec S.P., Roberton A.M., 1983. I Icterogeneity in gastrointestinal mucins. Biochim. Biophys. Acta 760, 262-269

Stanley R.A., Ram S.P., Wilkinson R.K., Roberton A.M., 1986. Degradation of pig gastric and colonic mucin by bacteria isolated from the pig colon. Appl. Environ. Microbiol. 51, 1104-1109

Tabuchi Y., Sugiyama N., Horiuchi T., Furuhama K., Furusawa M., 1997. Insutin stimulates production of g!ycoconjugate layers on the cell surface of gastric surface mucus cell line GSM06. Digeb. $58,28-33$

Tani S., Okuda M., Morishige R., Tanaka T., 1997. Gastric mucin secretion from cultured rat epithelial cells. Biol. Pharm. Butl. 20, 482-485

Turnberg L.A., 1987. Gastric mucus, bicarbonate and $\mathrm{pH}$ gradients in mucosal protection. Clin. Invest. Med. 10, 178.180

Vahouny G.V., Cassidy M.M., 1986. Dietary fiber and intestinal adaptation. In: G.V. Vahouny, D. Kritchevsky (Editors). Dictary Fiber: Basic and Clinical Aspects. Plenum Press, New York, pp. 181-209

Vahouny G.V., L.c T., Ifrim I., Satchithanandam S., Cassidy M.M., 1985. Stimulation of intestinal cytokinetics and mucin tumover in rats fed wheat bran or cellulose. Amer. J. Clin. Nutr. 41, 895-900

Van der Poel A.F.B., 1990. Effects of processing on antinutritional factors (ANF) and protein nutritional value of dry beans (Phaseolus vulgaris L.). A review. Anim. Feed Sci. Tech. 29, 179-208

Variyam E.P., Hoskins L.C., 1981. Mucin degradation in human colon ccosystems. Degradation of hog gastric mucin by fecal extracts and fecal cultures. Gastroenterology 81, 751-758

Variyam E.P., Hoskins L.C., 1983. In vivo degradation of gastric mucin. Carbohydrate side chains protect polypeptide core from pancreatic proteases. Gastroenterology 84, 533-537.

Vecchi M., Torgano G., Monti M., Berti E., Agape D., Primignani M., Ronchi G., Defranchis R., 1987. Evaluation of structural and secretory glycoconjugates in normal human jejunum by means of lectin histochemistry. Histochemistry 86, 359-364

Vercellotti J.R., Salyers A.A., Bullard W.S., Wilkins T.D., 1977. Breakdown of mucin and plant polysaccharides in the human colon. Can. J. Biochem. 55, 1190-1196

Wesley A., Forstner J.F., Forstner G.G., 1983. Structure of intestinal-mucus glycoprotein from human post-mortem or surgical tissues: inferences from correlation analyses of sugar and sulphate composition of individual mucins. Carbohyd. Res. 115, 151-163

Younan F., Pearson J.P., Allen A., Venables C., 1982. Changes in the structure of the mucosal surface of the stomach in association with peptic ulcer disease. Gastroenterology 82, 827-831

Żebrowska T., Low A.G., Żebrowska H., 1983. Studies on gastric digestion of protein and carbohydrate, gastric secretion and exocrine pancreatic secretion in the growing pig. Brit. J. Nutr. 49, 401-410 


\section{STRESZCZENIE}

\section{Wplyw diety na sekrecję i degradację mucyn w przewodzie pokarmowym zwierząt monogas- trycznych i czlowicka}

W opracowaniu przedstawiono stan dotychczasowych badań nad wpływem diety na sekrecję mucyn i ich zawartość w treści jelita biodrowego. Opisano ogólną strukturę mucyn i ich degradację w jelicje cienkim i grubym. Mucyny, będące ochronną warstwą całego przewodu pokarmowego, podlegają działaniu wszystkich chemicznych i fizycznych czynników trawiennych. Najważniejszym z nich jest protcolityczny rozkład mucyn do mniejszych cząstck, a następnic ich uwalnianic do światła jelita. Ubytki mucyn uzupełniane są przez ich syntezę i sekrecję z dolnych warstw nabłonka. Diety mogą wpływać na ten proces pośrednio przez ich oddziaływanie na procesy trawienne, z których najważniejszym jest ilość i rozmieszczenie enzymów proteolitycznych w świetle jelita, a także bezpośrednio poprzez siły fizyczne wywierające nacisk na nabłonek przewodu pokarmowego. Stwierdzono zmiany zdolności przystosowania aktywności w komórkach kubkowych w zależności od rodzaju skarmianej diety. W świetle jelita cienkiego stwierdzono tylko niewielką degradację mucyn, natomiast w jelicie grubym inucyna jest fermentowana przez zasiedlającą to jelito populację drobnoustrojów. Zawartość nie rozłożonej mucyny $w$ treści jelita biodrowego ma duże znaczenic w badaniach żywicniowych: po pierwsze ze względu na to, że możc powodować znaczne straty aminokwasów endogennych i węglowodanów, po wtóre, że może zmieniać oddziaływanie diet na przewód pokarmowy. 